Nig J. Biotech. Vol. 31 (2016) $96-102$

ISSN: 01891731

NIGERLAN JOURNAL OF

BIOTECHNOL OGY

Available online at

http://www.ajol.info/index.php/njb/index

and www.biotechsocietynigeria.org

DOI: http://dx.doi.org/10.4314/njb.v31i1.13

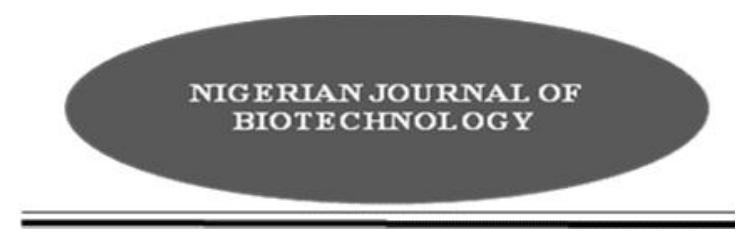

\title{
Prevalence of Rice Yellow Mottle Virus (RYMV) on Rice Plants Grown in Selected Farms in Ogun State: Preliminary Results
}

\author{
Odedara, O.O. ${ }^{1}$, Ademolu, K.O. ${ }^{2}$ and Ayo-J ohn, E.I. ${ }^{3}$ \\ ${ }^{1}$ Department of Microbiology, Federal University of Agriculture, Abeokuta, Nigeria \\ ${ }^{2}$ Department of Pure and Applied Zoology, Federal University of Agriculture, Abeokuta, Nigeria \\ ${ }^{3}$ Department of Crop Protection, Federal University of Agriculture, Abeokuta, Nigeria
}

\begin{abstract}
Incidence of Rice yellow mottle virus (RYMV) on rice plants (ofada) grown in two local government areas (LGAs) of Ogun State had been evaluated during a two year field survey. Six month old rice plants were observed for symptom expression and leaf samples collected for serological indexing. Of the 60 leaf samples collected for both years, $96.7 \%$ were presented with symptoms and severity ranged from 1 to 5 in 2012 . Symptoms of brown blotches, chlorosis, leaf yellowing and necrosis were observed on rice plants from which samples were collected at Ewekoro LGA. Similar symptoms were also seen on rice plants at Obafemi Owode. Disease incidence due to RYMV was $7.7 \%$ at Ewekoro in 2012 while it was $13.3 \%$ for plants surveyed at Obafemi owode in the same year. In 2013, incidence varied from 30.0 to $90.0 \%$ and the higher incidence was observed on samples at Obafemi owode. Serodiagnosis of Grasshopper (Zonocerus variegatus) and Locust (Locusta migratoides) trapped at the rice fields during the survey revealed that they were not implicated in virus transmission as their absorbance values at spectrophotometric wavelength of $\mathbf{4 0 5} \mathbf{~ n m}$ were not up to one and half times the values of the healthy controls.
\end{abstract}

Keywords: rice, ELISA, incidence, virus symptom, survey

Correspondence: sdara@hotmail.com

Introduction

With increase in world population, there is emphasis on increasing level of food production, among which is rice. Rice (Oryza spp.) is grown widely in many parts of the world. It is the major food source for about 40 $\%$ of the world's human population (Ortiz, 2011) Production of rice in Nigeria is being threatened by infections from various pathogens such as Rice yellow mottle virus (RYMV) and others such as Maize streak virus (MSV) (Alegbejo, 2013). The virus, Rice yellow mottle virus (RYMV) is a non-enveloped isometric virus belonging to the genus Sobemovirus. Its particle size is $25 \mathrm{~nm}$ in diameter with conspicuous capsomere arrangement. The biochemical properties of RYMV include its virions containing $23 \%$ nucleic acid, $77 \%$ protein and $0 \%$ lipid. It is a RNA virus, single stranded and its total genome size is $4.2 \mathrm{~kb}$ (kilobase).
RYMV has narrow experimental host ranges which include Oryza sativa, 0 . barthii and 0 . punctata. Symptoms of RYMV on 0 . sativa are chlorotic dottings of leaf bases, elongating parallel to veins to produce mottling and stunting. On 0 . barthii, Rice yellow mottle virus produces spots and vein streaking while on O. punctata, systemic chlorotic dots are produced. The disease which is characterized by mottle and yellowing symptoms of varying intensities depending on genotype and this could be mistaken with iron and nitrogen deficiency (Onasanya et al., 2006). Gnanamanickam (2009) stated that RYMVinfected rice plants usually develop pale yellow mottle leaves, stunted, reduced tillering, non synchronous flowering, poor panicle exertion and spikelet discolouration. 
RYMV was first reported in Nigeria in 1976 (Raymundo \& Buddenhagen, 1976; Rossel et al., 1982). It is known to be transmitted by mechanical contact mediated by wind (Sara et al., 2004), farm equipments (Abo et al., 1998) such as sickles used in harvesting and also by tight contacts between plants during planting out (Kouassi et al., 2005). Other methods of transmission of RYMV include guttation fluid and irrigation water (Abo et al, 1998; Abo et al., 2000). Cows, donkeys and grass rats had also been indicated as vectors of the virus through trampling and grazing (Sara et al., 2004).

It had been known that some species of rice plants are more susceptible to RYMV during the seedling and booting stages (Onwughalu et al., 2010). Such species include 'Moroberekan' and Bouake 189. It was also observed that yield losses to RYMV are strongly influenced by host cultivars as well as time of virus infection (Onwughalu et al., 2010)

Ogun state is one of the states producing rice in Nigeria. It lies in the latitude $6.2^{\circ} \mathrm{N}$ and $7.8^{\circ} \mathrm{N}$ and longitude $3.0^{\circ} \mathrm{E}$ and $5.0^{\circ} \mathrm{E}$. The climate of Ogun State follows a tropical pattern with the rainy season starting about March and ending in November. The mean annual rainfall varying from $128 \mathrm{~cm}^{3}$ in the southern part of the state to $105 \mathrm{~cm}^{3}$ in the northern areas.

In Nigeria, RYMV had been reported in Alamala farms in Ogun State, while there is paucity of information regarding viruses infecting rice planted by farmers at Obafemi Owode and Ewekoro local government areas (LGAs), This research was therefore carried out to identify RYMV infecting rice planted at Obafemi Owode and Ewekoro LGAs, check the prevalence of the virus on rice plants on these fields within two consecutive years and study the ability of grasshopper (Zonocerus variegatus) and Locust (Locusta migratoides) trapped from the field to be vectors for the virus.

\section{Materials and Methods}

Survey of fields were conducted in September 2012 and 2013 during which rice grains had been harvested by the farmers and leaf samples were collected from left over grown plants on the field. Two rice fields were surveyed in two local government areas of Ogun State where 'ofada 'rice production is massively practiced by the farmers. The local government areas included Obafemi Owode and Ewekoro. At each local government, a field was surveyed. Size of fields ranged from two to five and half acres. A total number of 10 to 20 leaf samples were collected randomly according to the method of Ochola \& Tusiime, (2011) from apparently healthy and infected plants. Plants from which samples were collected had viral symptoms appearances scored and the degree of severities recorded according to (Raymundo et al. (1979). Leaf samples of rice from both symptomatic and asymptomatic plants were collected and stored over Calcium chloride $\left(\mathrm{CaCl}_{2}\right)$ until serological indexing. Some insects namely Grasshopper (Zonocerus variegatus) and Locust (Locusta migratoides) observed on the rice fields were also collected and trapped in double layered polythene bags which were later kept at $4^{\circ} \mathrm{C}$ till serology test was carried out.

Serological indexing: Methods of double antibody sandwich enzyme-linked immunosorbent assay (DAS-ELISA) was adopted for the detection of RYMV both in rice leaf samples and guts of the trapped insects. It was first described by Clark and Adams (1977) but with modification from the virology laboratory of Deutche Sammullung von Mikroorganismen und Zellkuturen. The guts of insects were tested for the presence of a virus using DAS-ELISA after they had been brought out to room temperature for acclimatization from the refrigerator $\left(4^{\circ} \mathrm{C}\right)$. Their intestinal tracts were separated from the body mass through dissection by an Entomologist.

Protocols for DAS-ELISA: Microtitre wells of ELISA plates were coated with $100 \mu$ of appropriately diluted RYMV immunoglobulin G $(\mathrm{IgG})$ in coating buffer containing $1.59 \mathrm{~g}$ Sodium carbonate $\left(\mathrm{Na}_{2} \mathrm{CO}_{3}\right)$ and $2.93 \mathrm{~g}$ Sodium bicarbonate $\left(\mathrm{NaHCO}_{3}\right)$ per litre, $\mathrm{pH}$ 9.6. Plates were incubated at $37^{\circ} \mathrm{C}$ for $2 \mathrm{~h}$ after which the contents were decanted and wells washed three times with single strength phosphate buffer saline containing $0.05 \%$ tween $20(\mathrm{v} / \mathrm{v})$ (PBS$\mathrm{T})$. Constituents of PBS-T include $8.0 \mathrm{~g}$ Sodium chloride $(\mathrm{NaCl}), 0.2 \mathrm{~g}$ monobasic potassium phosphate $\left(\mathrm{KH}_{2} \mathrm{PO}_{4}\right), 1.15 \mathrm{~g}$ dibasic Sodium phosphate $\left(\mathrm{Na}_{2} \mathrm{HPO}_{4}\right)$ and $0.2 \mathrm{~g}$ Potassium chloride $(\mathrm{KCl})$ per litre, pH 7.4. ELISA plates were tapped dry and $100 \mu$ l aliquots of extracted sap of infected rice leaves and macerated insects' guts including the negative and positive 
controls provided were pipetted into the duplicate wells and incubated overnight in the refrigerator at $4^{\circ} \mathrm{C}$. Contents of wells were decanted and wells washed as previously described. One hundred microlitre of appropriately diluted enzyme-labelled antibody (IgG-alkaline phosphatase) in conjugate buffer (1.0 g polyvinyl pyrrolidone[PVP], $0.1 \mathrm{~g}$ egg albumin/L PBST) was added to each well and incubated at $37{ }^{\circ} \mathrm{C}$ for $2 \mathrm{~h}$. Wells were washed and plates tapped dry before $100 \mu \mathrm{l}$ of $1 \mathrm{mg} / \mathrm{ml}$ para-nitrophenyl phosphate dissolved in substrate buffer $(97 \mathrm{ml}$ diethanolamine/L, $\mathrm{pH}$ 9.8) was added per well and contents incubated at room temperature for $1 \mathrm{~h}$ and/or overnight at $4{ }^{\circ} \mathrm{C}$, after which the spectrophotometric reading was taken using an ELISA plate reader (model MR-96, MINDRAY, China) at $405 \mathrm{~nm}$. Sample was considered positive when the mean of its absorbance values is one and a half times the average value of the healthy (negative) control (Hughes and Tarawali, 1999).

\section{Results}

During the two year survey, a total of 60 rice leaf samples were collected from both locations, out of which $96.7 \%$ were symptomatic while the remaining were asymptomatic. Eighty percent (48 of 60) were serologically tested during the two year survey in which, $4.2 \%$ (2 of
48) were asymptomatic. Of these asymptomatic samples, $2.1 \%$ (1 of 48 ) tested positive for RYMV. In all, $31.3 \%$ (15 of 48 ) of the rice leaf samples tested were positive for RYMV.

On the fields, symptoms induced by RYMV such as necrotic lesions, leaf yellowing and brown blotches which are also known as brown streaking were among the several symptoms encountered during the survey. These symptoms occurred in varying levels of incidence. In 2012, brown streaking had highest incidence $(70.0 \%)$ at Apalolo in Ewekoro LGA followed by chlorosis ( $45 \%$ ) and necrosis (10.0 $\%)$. At Obafemi Owode in the same year, necrosis had an incidence of $65.0 \%$ followed by brown streaking $(35.0 \%)$ while yellow streaking accounted for $30.0 \%$ (Table 1 ).

In 2013, brown streaking had an incidence of $90.0 \%$ at Apalolo in Ewekoro LGA followed by leaf yellowing $(10.0 \%)$. At Lajila in Obafemi Owode LGA, necrosis had incidence of $60.0 \%$ and brown streaking as $40.0 \%$ (Table $1)$. Severities of symptoms absolutely varied when compared among the samples collected during the two year surveys. At Ewekoro in 2012 , only $55.0 \%$ of the samples collected had severity of 2 while none was observed showing similar severity at Obafemi Owode LGA in the same year. However, plants with the severity of 3 had highest incidence (Figure 1).

Table 1: Percentage incidence (\%) of viral symptoms observed on rice plants surveyed

\begin{tabular}{lllllllllll}
\hline Location & LGA & Year & \multicolumn{2}{c}{ Symptom observed: } \\
& & & $\begin{array}{l}\text { Brw } \\
\text { blch. }\end{array}$ & Chl. & $\begin{array}{l}\text { Lf. } \\
\text { Yell. }\end{array}$ & $\begin{array}{l}\text { Vein } \\
\text { clr. }\end{array}$ & $\begin{array}{l}\text { Vein } \\
\text { strk. }\end{array}$ & Nec. & AppH. & $\begin{array}{l}\text { Yell } \\
\text { strk. }\end{array}$ \\
\hline Apalolo & Ewekoro & 2012 & 70.0 & 45.0 & 5.0 & 5.0 & 5.0 & 10.0 & 5.0 & 0.0 \\
Lajila & $\begin{array}{l}\text { Ewekoro } \\
2013\end{array}$ & 90.0 & 0.0 & 10.0 & 0.0 & 0.0 & 10.0 & 10.0 & 0.0 \\
& $\begin{array}{l}\text { Obaf. } \\
\text { Owode }\end{array}$ & 2012 & 35.0 & 20.0 & 5.0 & 0.0 & 0.0 & 65.0 & 0.0 & 30.0 \\
& $\begin{array}{l}\text { Obaf. } \\
\text { owode }\end{array}$ & 2013 & 40.0 & 0.0 & 20.0 & 0.0 & 0.0 & 60.0 & 0.0 & 0.0 \\
\hline
\end{tabular}

Key: Brw blch: brown blotching; chl.-chlorosis; Lf yell.-leaf yellowing; vein clr.-vein clearing; vein strk.vein streaking; nec.-necrosis; AppH-apparently healthy; Yell strk.-yellow streaking 


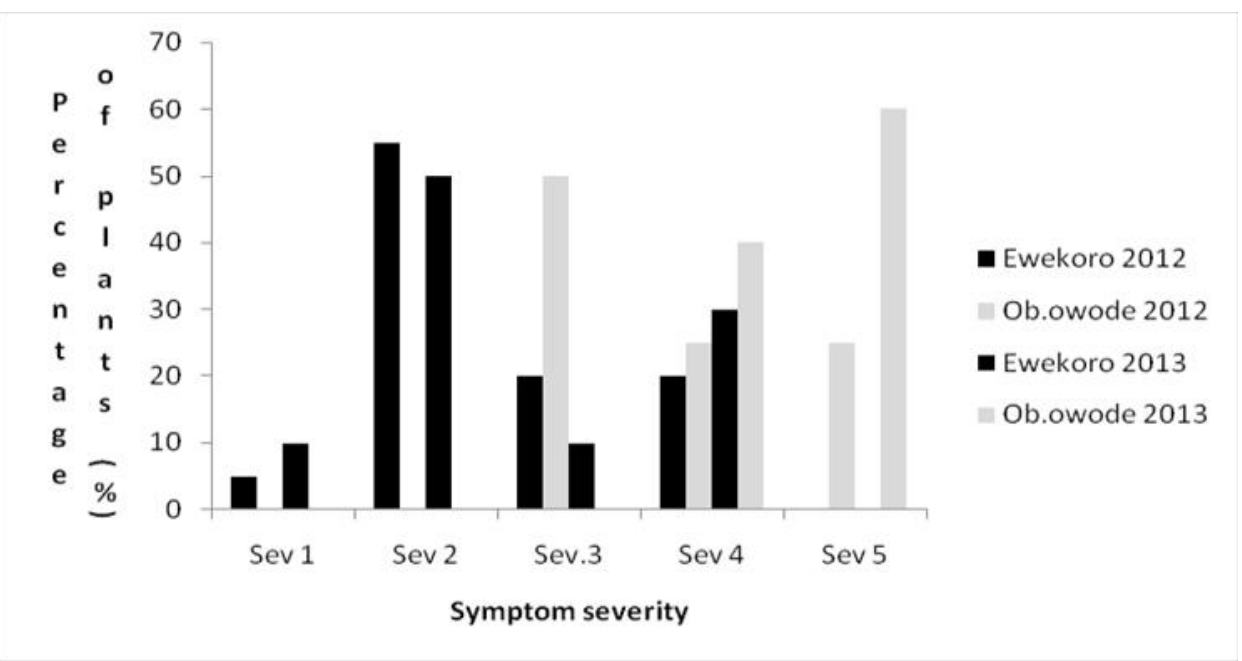

Figure 1: Percentage of rice plants exhibiting various symptom severities

When serological indexing was performed on the leaf samples collected, RYMV was detected in $10.7 \%$ of the total leaf samples tested from both locations in 2012 while the incidence was $60.0 \%$ in 2013. Considering the two LGAs in 2012, the higher incidence of RYMV was detected in leaf samples collected from
Obafemi Owode $(13.3 \%)$ while the high incidence was detected in samples from Ewekoro (7.7 \%). In 2013, RYMV was detected in $90.0 \%$ of the leaf samples collected and tested from Obafemi Owode LGA while it was detected in $30.0 \%$ of the leaf samples collected and tested from Ewekoro LGA (Table 2).

Table 2: Incidence of Rice yellow mottle virus (RYMV) on rice plants as detected by enzyme linked immunosorbent assay (ELISA)

\begin{tabular}{lllll}
\hline LGA & Year & $\begin{array}{l}* \text { No. colltd } \\
(\mathrm{n})\end{array}$ & No. tested & $\begin{array}{l}\text { Percentage } \\
(\%)\end{array}$ \\
\hline Ewekoro & 2012 & 20 & 13 & 7.7 \\
& 2013 & 10 & 10 & 30.0 \\
Obafemi owode & 2012 & 20 & 15 & 13.3 \\
& 2013 & 10 & 9 & 90.0 \\
\hline
\end{tabular}

*Number collected

The two types of insects collected during the two year surveys included the grasshopper (Zonocerus variegatus) and Locust (Locusta migratoides). Evidence of ELISA results showed that there was no serological detection of RYMV from the guts of both sets of insects during the two year survey as their mean of absorbance values at $405 \mathrm{~nm}\left(\mathrm{~A}_{405 \mathrm{~nm}}\right)$ were not measured up to one and half times the absorbance values of the healthy controls. The absorbance values of guts of $Z$. variegatus in 2012 ranged between 0.743 to 0.807 from both LGA, while the healthy value was 0.688 (Table 3). Locust trapped from rice field at Apalolo (Ewekoro LGA) also had an absorbance value of 0.744 in 2012 as against the value (0.688) of incorporated healthy control. In the same year, Locust was not trapped from the field at Obafemi Owode LGA (Table 3). 
Table 3: Serological status of insects collected from rice fields during survey

\begin{tabular}{|c|c|c|c|c|c|c|}
\hline LGA/Village & Year & $\begin{array}{l}\text { Type of } \\
\text { insect }\end{array}$ & $\begin{array}{l}\text { Scientific } \\
\text { name }\end{array}$ & $\begin{array}{l}\text { No. } \\
\text { collected }\end{array}$ & $\begin{array}{l}\text { Mean of } \\
\text { Absorbance } \\
\text { at } \quad 405 \\
\mathrm{~nm}\left(\mathrm{~A}_{405 \mathrm{~nm}}\right)\end{array}$ & $\begin{array}{l}\text { Mean of } \\
\text { absorbance } \\
\left(\mathrm{A}_{405 \mathrm{~nm}}\right) \text { of } \\
\text { healthy } \\
\text { control }\end{array}$ \\
\hline \multirow[t]{3}{*}{ Apalolo/Ewekoro } & 2012 & Grasshopper & $\begin{array}{l}\text { Zonocerus } \\
\text { variegatus }\end{array}$ & 1 & 0.807 & 0.688 \\
\hline & & Locust & $\begin{array}{l}\text { Locusta } \\
\text { migratoides }\end{array}$ & 1 & 0.744 & 0.688 \\
\hline & 2013 & Nil & - & - & - & - \\
\hline \multirow{3}{*}{$\begin{array}{l}\text { Mokoliki/Obafemi } \\
\text { owode }\end{array}$} & 2012 & Grasshopper & Z. variegatus & 1 & 0.743 & 0.688 \\
\hline & 2013 & Grasshopper & Z. variegatus & 1 & 0.688 & 1.037 \\
\hline & & Locust & $\begin{array}{l}\mathrm{L} . \\
\text { migratoides }\end{array}$ & 1 & 1.023 & 1.037 \\
\hline
\end{tabular}

\section{Discussion}

Viral disease due to RYMV had been a major challenge in rice production in Nigeria since 1976 when it was reported by Rossel et al. (1982). Areas of rice production in Nigeria where the virus had been detected included Badeggi, Ibadan, Abeokuta, Alamala (Rossel et al., 1982; Onasanya et al., 2011) in Ogun State, but this is the first report of RYMV occurring on rice plants at Obafemi Owode and Ewekoro LGAs in Ogun State, Nigeria.

The viral symptoms observed on the field had been the usual symptoms of RYMV that had been earlier described and these include mottling and yellowing. However a variety of symptoms are observed on some cultivars or under specific growing conditions including streaks and whitening on leaves and in severe cases, necrosis of the plants. Infection results in stunting of the plant, reduced tillering, poor panicle exertion and sterility. Death of the plants of susceptible cultivars occurred after early infection (Bakker, 1974; Calvert et al., 2003).

The detection of RYMV on rice plants at both locations indicated that rice plants (ofada) under production in the two local governments surveyed are under viral attack and this may probably affect yield, though the value may be minimal that it goes unnoticeable. During the two years survey, symptoms and severities varied in both locations alongside with incidence. The incidence of RYMV observed by Onasanya et al. 2011 on farmer's field ranged between $15-70 \%$. This is in contrast to this study as an incidence of $7.7 \%$ was observed in 2012 at Ewekoro while the highest incidene of
$90.0 \%$ was noticed in 2013 at Obafemi Owode LGA. Though these values are not similar, they are still very high. Continuous recording of high RYMV incidence values on rice plants is of great challenge and demands urgent attention. The high incidence must have also been due to different types of wild plants and volunteer weeds surrounding the two farms.

The serological diagnosis showed that rice samples from Obafemi owode were more infected than the ones collected from Ewekoro, the reason might be due to the presence of abundant RYMV vectors at the former location than the latter or the presence of alternate hosts which harbour the virus and serve as reservoir during the new planting season. The natural host range of RYMV is restricted to a few members of Graminae family, i.e. Eragostidae and Oryza sp. The most commonly species are 0 . sativa, 0 . longstaminata, 0 . barthii, Echinochloa colona, Ischaemum rugosum, Panicum repens. A few additional Poaceae had been infected experimentally (Bakker, 1974). So also, farmers claimed to have planted from previous season's seeds but this is unlikely to have contributed to the high incidence as seed transmission of this virus had not been reported (Konate et al., 2001). The occurrence of a latent infection in this study is of great challenge as this has not been earlier reported. The presence of latently-infected rice plant among others might prevent the rouging of such plant, which is one of the controlling methods in agricultural practices. 
Though Bakker (1974), stated that RYMV was occasionally transmitted by biting insects such as grasshopper (Conocephalus), in a non-persistent manner, similar result was not observed on the grasshopper (Zonocerus variegatus) and locust (Locusta migratoides) that were serologically tested in this research. Probably because of the period of the year the insects were collected or the insects have not fed on infected rice plants.

There is need for training and retraining of farmers and stakeholders involved in rice production to employ sanitary measures during planting. This will go a long way to reduce the incidence of RYMV as most of the farmers claimed to burn the left over rice plants before subsequent planting. This method might not completely eradicate the rice plants which during the favourable weather (rainy season)

\section{References}

Abo, M., Sy, A. and Alegbejo, M. (1998). Rice yellow mottle virus (RYMV) in Africa: Evolution distribution, economic significance and sustainable rice production and management strategies. Journal of Sustainable Agriculture 11: 85-111

Abo, M., Alegbejo, M., Sy, A. and Misari, S. (2000). An overview of mode of transmission, host plants and methods of detection of rice yellow mottle virus. Journal of Sustainable Agriculture 17: 19-36.

Alegbejo, M.D. (2013). Virus and virus-like diseases of crops in Nigeria. Ahmadu Bello University Press. Kaduna, Nigeria. Pp. 27.

Bakker, W. (1974). Characterization and ecological aspects of rice yellow mottle virus in Kenya Agricultural Research Report. Wageningen.. 829: 1-152.

Calvert, L.A., Koganezawa, H., Fargette, D. and Konate, G. (2003). Rice. In: Thottappilly, G. and Loebenstein, G. Virus and virus-like diseases of major crops in developing countries. Kluwer Academic Publishers. Netherlands. Pp 269-294.

Clark, M.F. and Adams, A.N. (1977). Characteristics of the microplate method of enzyme linked immunosorbent assay for the might re-grow and act as probable source of inoculum. Most of the fields were surrounded with fallow lands with overgrown weeds which might have harboured the virus till subsequent season. There a need for farmers to be informed of application of sanitary measures during planting of seeds. The use of hybrid seeds with resistance to RYMV is also recommended for the farmers.

In conclusion therefore, it was investigated in this study that infection of rice plants caused by Rice yellow mottle virus occurred in 'ofada' rice plants grown in Ewekoro and Obafemi owode LGAs of Ogun state. The incidence was higher on plants grown in the latter LGA. Severity ranged from 1 to 5 and diverse symptoms were observed. This information is important for the management control to be set up for rice disease in the areas.

detection of plant viruses. Journal of General Virology 34: 574-586.

Gnanamanickam, S.S. (2009). Biological control of Rice Diseases. Volume 8. The Netherlands. Pp 13-42.

Hughes, J.d'A. and Tarawali, S.A. (1999). Viruses of herbaceous legumes in the moist savanna of West Africa. Tropical Science 39: 7076.

Konaté, G., Sarra, S. and Traoré, O. (2001). Rice yellow mottle virus is seed borne but not seed transmitted in rice seeds. European Journal of Plant Pathology 107: 361-364.

Kouassi, N.K., N'Guessan, P., Albar, L., Faquet, C.M. and Brugidou, C. (2005). Distribution and Characterization of Rice yellow mottle virus. A threat to African Farmers. Plant Diseases 89: 124-133.

Ochola, D. and Tesiime, G. (2011). Survey on incidences and severity of Rice yellow mottle virus in Eastern Uganda. International J ournal of Plant Pathology 2: 15-25

Onasanya, A., Sere, Y., Sie, M., Akator, K., Coulibaly, M.M. and Hamadoun, A. (2006). Existence of two pathotypes of Rice yellow 
mottle virus, genus Sobemovirus in Mali. Plant Pathology J ournal 5: 368-372

Onasanya, R.O., Olufolaji, D.B., Onasanya, A., Sere, Y., Nwilene, F.F., Woperels, M. and Kiepe, P. (2011). Occurrence, distribution and characterization of Rice yellow mottle virus isolates genus Sobemovirus in Southwestern Nigeria. Trends in Applied Science Research 6: 1301-1323.

Onwughalu, J.T., Abo, M.E., Okoro, J.K., Onasanya, A. and Sere, Y. (2010). Rice yellow mottle infection on the performance of rice (Oryza sativa L.) Relative to time of infection under screenhouse condition. Journal of Applied Science. 1-4.

Ortiz, R. (2011). Agrobiodiversity management for Climate change. CAB International 12: 189211.
Raymundo, S.A. and Buddenhagen, I.W. (1976). A rice disease in West Africa. Int. Rice Comm. Newslett. 25: 58.

Raymundo, S.A., Buddenhagen, I.W., Fomba, S.N. and Akibo-Betes, D.T. (1979). Recent Advances in knowledge of rice viruses and resistance to beetle transmitted mottle of rice in West Africa. Proceeding of the $6^{\text {th }}$ Seminar on Rice Breeding and varietal improvement (RBV 179). ADRAO, Moronvia, Liberia. Pp 203-212.

Rossel, H.W., Ayotade, K.A., Thottappilly, G., Adeoti, A.A., Alluri, K., Alam, M.S. and Zen, K. (1982). A new record of rice yellow mottle virus disease in Badeggi, Nigeria. International Rice Communication Newsletter 31: 23-24.

Sarra, S., Oevering, P., Guido, S. and Peters, D. (2004). Wind mediated spread of rice yellow mottle virus (RYMV) in irrigated rice crops. Plant Pathology 53: 148-153. 